\title{
IMPACT OF PERCEPTION AND ATTITUDE TOWARDS THE STUDY OF AFRICAN LANGUAGES ON HUMAN RESOURCE NEEDS: A CASE FOR ZIMBABWE
}

\author{
Ruth Babra Gora \\ University of Zimbabwe \\ Davie Elias Mutasa \\ University of South Africa
}

This article argues that the Zimbabwean high school curriculum has remained largely irrelevant to human resource needs for professions that draw expertise from African languages, such as teaching, translating, broadcasting and interpreting. Despite some curriculum reforms after the attainment of political independence, effects of colonial language policy and language planning with regard to the Zimbabwean education system seem to have remained intact. As a result, observations have been made that the system continues to churn out Africans who are still deeply rooted in the belief that the study of foreign languages, English in particular, prepares them for a better and brighter future than African languages would. The belief is largely that a pass in English guarantees them better, higher-paying, more prestigious and more readily available jobs than would African languages. The education system in Zimbabwe today, this paper argues, has negative perceptions and attitudes towards the study of African languages. African languagesrelated professions are therefore filled by people with little or no sound background knowledge in the area. In addition, those who end up being absorbed in professions that draw from the African languages area, in most cases, are not satisfied. The same can be said of most other African countries that were subjected to colonialism in the past and neo-colonialism today, under the vague and obscure concepts of globalisation and modernisation. Against this backdrop, the article advocates for the re-engineering of the Zimbabwean school corecurriculum by incorporating mandatory study of an indigenous language, at least up to ' $O$ ' level, in a bid to preserve and promote African languages and at the same time meet human resource needs of professions that draw from the discipline over time.

\section{Keywords}

Perception; attitude; African languages; human resource

\section{INTRODUCTION}

Zimbabwe, like most African countries, is multilingual. During colonial rule in Zimbabwe, English was positioned at the apex of the multilingual scenario, while African languages were accorded an inferior position. English was the medium of instruction in schools and the language of all forms of administration. The local people had no choice but to accept English and its influence. Consequently, being competent in English was equated to being educated and it was a 
source of pride to many. Thus, primacy was given to English in social, economic and educational spheres, to the detriment of African languages.

This article explores how such a state of affairs has been perpetuated despite Zimbabwe having attained political independence 34 years ago. The article thus examines perceptions and attitudes towards the study of African languages in Zimbabwean high schools before highlighting the impact on human resource issues in related fields. Ways to affirm the relevance of African languages in education are suggested as the article argues against the notion that English offers a better professional future than local languages.

While some scholars may argue that, in the face of globalisation and modernisation, the study of indigenous languages no longer matters much, this paper maintains that there is great need for such specialisation for the development and management of human resources that draw from these languages. The Zimbabwean education system is still haunted by the diglossic landscape created and crafted by colonial language policies. Hence, the issue of perceptions and attitudes with regard to teaching/learning of African languages in the Zimbabwean curriculum remains topical.

Three fundamental questions guide the discussion in this paper:

- From a historical point of view, have the perceptions and attitudes towards the study of African languages in Zimbabwean high schools changed?

- How do those perceptions and attitudes influence human resource potential in areas that draw from the African languages discipline?

- As a way forward, how can the study of African languages be redefined in order to meet human resource needs in African languages-related professions?

To address these questions, among other related issues, the paper begins by giving a brief background on language planning and policy in Zimbabwe regarding language in education.

\section{BACKGROUND}

During colonial rule in Zimbabwe, as highlighted above, English dominated the linguistic landscape. Surprisingly, 34 years into political independence have not yielded any parallel linguistic independence. English remains the defining language in major sectors of national, economic, educational, political and social discourse. Despite the introduction of some language policy initiatives after the attainment of independence, Zimbabwe has failed to resuscitate a significant status of African languages. Adjibolosso (1995) notes that sub-Saharan African countries seem to be failing to translate their political independence into successful democracies and fortresses of economic development because of the absence of a positive human factor in education and training.

Through the Education Act (1987), for instance, Zimbabwe tried to raise the status of Shona and Ndebele by ascribing them national language status so that the languages would be used as media of instruction up to Grade 3. This did not come to full realisation as, in a study by Mutomba (2007), some schools were found not to be taking heed of this directive. It was observed that some parents, including educators, even enrolled their children in schools where English was the medium of instruction right from the beginning of the educational ladder. 
Then in 1999, the Nziramasanga Commission recommended that use of Shona and Ndebele as media of instruction in schools be extended to Grade 7 level. It was only seven years later, in 2006, that the government of Zimbabwe tried to buy into this recommendation by amending the Education Act (1987). The amended Education Act (2006) now stipulated the use of Shona and Ndebele as languages of instruction up to Grade 7, though the position of the other minoritised indigenous languages was still not very clearly espoused. Escape clauses, observed by Bamgbose (1991: 62) in most language policies of African nations, such as 'minority languages could be used subject to availability of manpower' or 'with the approval of the minister', in the amended act, show lack of political will on the part of the government.

The language situation in Zimbabwe is that Shona and Ndebele have been given precedence when it comes to language teaching/learning in the education system. Although the two languages are taught and learnt from Grade 0 up to tertiary level, according to Gudhlanga and Makaudze (2005) there generally seems to be negative perceptions and attitudes towards the study of African languages. Drawing from such findings, this paper seeks to determine the impact of such negative perceptions and attitudes on human resource needs.

It is important to note that the teaching of some of the minoritised languages is also underway from Grades 1 to 7. Examining of Tonga at Grade 7 level began in 2011, while that of Venda, Nambia and Kalanga started in 2012, and that of Xichangana was pencilled for 2013 (Dube, 2012). However, preparations to have the languages taught and examined at secondary school level are at a very slow pace although the syllabi have been availed to schools. What disturbs is the fact that in most instances the teachers assigned to teach Tonga language as a subject in primary schools are not qualified to do so (Gora, Mavhunga, Muringai \& Waniwa, 2010). In primary teacher training colleges, a student teacher is prepared to teach all the primary school subjects but, if one is not a Tonga language specialist, no matter how sound the methodology one has acquired and mastered, a mismatch is created from a pedagogical point of view. It is logical that, for teaching/learning to effectively take place, there must be equally effective and meaningful communication between the teacher and the learner. This requirement is therefore not met when the teacher who has not specialised in Tonga is expected to teach learners of the language.

One university in the country has, however, taken a positive move as it offers courses in Venda, Kalanga, Tonga and Shangani languages at degree level. Unfortunately, those successfully acquiring the degree eventually go to South Africa for greener pastures, where the languages are overtly offered as subjects of the curriculum (Gudhlanga \& Makaudze, 2005), thus negating what started off as a step in the right direction. At the moment, the Zimbabwean curriculum has not effectively offered local languages as subjects of study in the education system to retain the few specialists in said minoritised languages.

In the late 1990s one primary teacher training college was also given the mandate to train Tonga language teachers. Research carried out in the Nyaminyami District of Mashonaland West Province in Zimbabwe established that the community, parents, teachers and headmasters professed ignorance to such information (Gora et al, 2010: 89). The noble idea lacked publicity, hence it cannot be expected that Tonga speakers ever dream of working in a Tonga languagerelated job.

Per Linguam 2015 31(1):74-88

http://dx.doi.org/10.5785/31-1-634 
The linguistic landscape in Zimbabwe, where languages enjoy different statuses, brings to the fore issues of perceptions and attitudes towards the study of African languages. The education system is driven towards categorising English as part of the core curriculum at the expense of the indigenous languages, thus creating an imbalance in human capital management and development in spheres requiring expertise in the local languages. Failure by the education system to implement language policy initiatives could be regarded as a pointer to perceptions and attitudes towards the study of African languages.

The discussion above shows then that once the education system is unable to create products specifically prepared for African languages needs, the discipline is bound to have gaps in rolling out and placement of relevant human potential. People are channelled into different professional fields depending on the subjects specialised in at school and higher learning institutions. There is a vicious cycle created right from the study of African languages at early stages of education up to the development of human capital in related areas.

\section{THEORETICAL FRAMEWORK}

The Zimbabwean curriculum is underscoring the central role of studying African languages in preparing a labour force in related professions. The curriculum covertly prescribes English as the 'best' language that can be studied in the classroom (Gora, 2014). This article thus argues that the study of local languages should be fostered in the curriculum. The theoretical framework that guides such thinking is reconstructionism.

Reconstructionism is grounded on the fact that education systems should be aware of social responsibilities and therefore the school should commit itself to specific social reforms (Akinpelu, 1985; Kneller, 1971). The defining tenets of educational reconstructionism show that there is great need for a fresh look at the school curriculum. Education should serve as a tool for immediate and continuous change of society. Reconstructionism is more concerned with the broad social and cultural fabric in which people exist. The argument is that social and cultural conditions should be made more suitable for human participation, development and management.

According to the father of reconstructionism, Theodore Brameld, and other scholars who subscribe reconstructionism, education stands for change and this should be positive change (Brameld, 1971). In light of that, the purpose of schools is therefore to bring about positive change in society, such as improved perceptions and attitudes towards African languages, which in turn instill a positive human factor. The article thus borrows from the reconstructionist's lens that the Zimbabwean high school curriculum must be re-engineered in terms of which subjects should be practically considered as core curriculum. The society needs constant reconstruction of education and the use of education in reconstructing the society (Ozmon \& Craver, 1986: 134). This calls for the school to function as a social agent by linking thought with action, theory with practice and intellect with activism. The school is strategically positioned to meet the crisis and provide the necessary human resources for African languages-related professions. It is on this premise that the article is grounded.

Per Linguam 2015 31(1):74-88

http://dx.doi.org/10.5785/31-1-634 


\section{FUNCTIONS AND STATUS OF LANGUAGE}

There is specialisation of language functions in any multilingual society. Languages enjoy different statuses in different situations. The choice of which language to study at high school, among many, can be directly linked to the aspects of language status and function. A language that offers opportunities in life during and after schooling is important and studying it becomes worthwhile.

Language functions and statuses can best be explained by adopting and adapting Ferguson's (1959) description of a situation where some language varieties are used for formal and public occasions as opposed to ordinary language. Ferguson (1959, in Wardhaugh 1998: 87) refers to such a situation as diglossia and describes diglossia as:

... a relatively stable language situation in which ... there is a very divergent, highly codified ... superposed variety, the vehicle of a large and respected body of written literature ... which is learned largely by formal education and is used for most written and formal spoken purposes but it is not used by any sector of the community for ordinary conversation.

In general terms, in a diglossic situation languages are ascribed with 'High' and 'Low' variety tags depending on Ferguson's nine rubrics, namely prestige/status, literary heritage, acquisition, standardisation, stability, grammar, phonology and lexicon (Fishman, 2002: 272). All these determine whether a language or language variety is important in a society or not, and this has an indirect bearing on the school curriculum. It is natural that, given a choice, one would opt to study that language which occupies a prestigious position in the hierarchy. Adjibolosso (1996: 3) reiterates that '... humanity will always do what gives food, clothing and shelter'.

A very close relationship exists between the functions that a language performs and its status. Language functions actually determine the status of a language. The more the functions a language has, the more prestigious it is (Benson, 2004: 65). This also determines how important a language is and consequently gives room for its study at high school, which is significant to this article's concerns.

An official language is one that is used as the language of government administration, scientific developments and trade. Such a language becomes the High variety $(\mathrm{H})$ and is esteemed as highly prestigious even in the face of political independence; it continues to ride the crest while African governments take time to uplift the status of indigenous languages (Prah, 2005). For Zimbabwe the official language, English, is more prestigious, while the national languages are not (Hachipola, 1998). This fact seems deeply entrenched in the Zimbabwean education system. This impacts on human resource issues in areas which require expertise in African languages.

\section{LANGUAGE AND EDUCATION}

Education is the basis of mass participation, social mobility, manpower training and development of human potential among other benefits (Bamgbose, 1991: 62). It is very difficult to say what language to prioritise in education in a multilingual country like Zimbabwe. WaThiongo (in Ouane, 2003) contends that the language used in education is the language of power. However, it is saddening to note that a large portion of the population in Africa are not competent in the 
languages of power in their countries. Skutnabb-Kangas (in Ouane, 2003) laments that one of the most successful means of destroying or retarding languages has been, and is, education. Educational curriculum decides the importance of a language. In education, language has three purposes, which are: literacy, subject and medium of instruction (Bamgbose, 1991).

This article's interest lies in language as a subject of the curriculum. In light of that, education must be concerned with the unleashing of the human potential for the welfare of not only the individual, but also the community at large. Language empowers the speakers. Vambe (in Mutasa, 2006:10) notes that speaking an African language does not automatically guarantee one's ability to do well if tested in that language. Speakers of African languages should therefore study and acquire the skill of using their own languages and that becomes very important in human resource production for concerned professions.

During colonial days, mother-tongue education basically had the following purposes:

- for initial literacy;

- as language of instruction at lower primary level; and

- as a subject of study from primary to higher levels of education.

This still remains today; the role of African languages has not changed. There is a need to dispel some unfounded myths concerning languages.

\section{MYTHS ABOUT MOTHER-TONGUE EDUCATION}

Benson (2004) describes some myths and attitudes that are regularly used to challenge mothertongue education. These include the following:

- the one nation-one language myth, which believes that use of a colonial language in education unifies a nation;

- the local languages cannot express modern concepts myth;

- the either-or myth, which claims that bilingualism causes confusion;

- the L2 as global language myth, which is a deliberate political promotion of foreign languages; and

- the parents are for L2-only schooling myth.

In the same vein, Kembo-Sure (in Mutasa, 2006: 13) identifies another folk theory or myth on language in education: that everyone just needs to learn English. All these downplay the importance of mother-tongue education and indirectly influence attitudes and/or perceptions towards the study of African languages in Zimbabwean high schools.

Language education choices also have to consider sociocultural aspects of language. The desire that a people's culture be preserved, culture which is represented by that people's language, should not be underestimated. This means that any system of education should consider giving all learners the opportunity of learning their language or learning in it. Usually, there is a danger of trying to weigh costs of educating people (in) their language for cultural survival against the need for technological development (Bamgbose, 1991: 79). This argument is extended to the need of providing learners with an effective education to equip them for the modern world. This 
further hinders the desire to inculcate appropriate culture in a child through an indigenous language in the face of an opposing 'more lucrative' foreign language.

The other constraint related to mother-tongue education relates to politics. While educationists may know what to do, they need to be empowered to implement policies (Mnkandla, 2000: 91). Generally, many governments hold the assertion that language policy matters are sensitive (Bamgbose, 1991). Possibly that is why governments, especially in Africa, are hesitant to alter existing language policies where drifting towards mother language is involved. It has been noted in most African countries that governments facilitate debates about emphasising mother-tongue education but conveniently carry on with education in a language of wider communication.

The greatest stumbling block faced in studying African languages in Zimbabwean secondary school education is the low status associated with it (Bamgbose, 1991: 95). Reasons that are often given for such attitudes and perceptions are:

- The industry does not seek specialists of African languages on the job market.

- Passing an African language is not a prerequisite for most post-secondary school studies. English, on the other hand, is a required subject in post-secondary school life.

- African languages are only recognised for courses in the language or for jobs which require use of the language, such as broadcasting, in addition to the English language requirement.

- The brighter students tend to go for other languages such as French, other than English, because they think that African languages will not help them at any stage in life.

As long as African languages continue to be accorded low status, this will continue to impact on their study and consequently on personnel needs of related areas.

Contrary to the situation in secondary schools, it is surprising that African language study is increasingly being taken more seriously in institutions of higher learning. There is a lot of research and innovation with African languages at tertiary level. A lot is being done at these institutions with the aim of improving mother-tongue education at lower levels and not for work life. In the same vein, most teachers' colleges and universities in Zimbabwe are also advocating for and researching into mother-tongue education (Chapanga \& Makamani, 2006).

\section{MOTHER-TONGUE EDUCATION FOR WORK LIFE}

During colonialism Africans were disempowered through deliberate strategies of not promoting and preserving African languages. This shows that colonialists viewed languages as an economic resource and for that same reason African languages should be used to empower their speakers. Uju (2008, in Rwantabangu, 2011), observes that language is inextricably linked to economic development. Mutasa (2003), Mazrui (1978), waThiongo (1996) and Mavesera (2009) also concur that language is a resource for economic development. Webb (2002) corroborates that language can facilitate or hinder economic activity. Language utilises the worker's skills and knowledge productively. It enhances effective delivery of services to the public. Language study in the school system therefore has implications on human resource management and development. 
WaThiongo (1996) maintains that language encompasses heritage, culture and feelings. Language fosters a strong sense of belonging and confidence that builds self-esteem. Self-esteem is necessary for socio-economic assertiveness. Mutasa (2003) notes that it looks like African languages are restricted to oral communication between co-workers in the workplace. African languages rescue workers where they have limited proficiency and/or vocabulary in the foreign language. This means that lack of language proficiency and/or vocabulary is a drawback in the workplace as it lowers productivity. Adjibolosso (1995) observes that many African countries have overlooked the provision of relevant education and/or training to help equip the labour force with abilities to manage development and production, thus creating a negative human factor which adversely affects performance.

Webb (2002) further notes that language is important in the development of vocational skills. Language is therefore an instrument of both education and training. Relevant education programmes should train and equip the labour force with appropriate human qualities in order to become efficient and productive (Adjibolosso, 1995; Ofori-Amoah, 1995). Human qualities like integrity, loyalty, accountability, honesty and dedication are too relevant to the human enterprise to be neglected by and for Africans. This article maintains that African languages provide a springboard for such virtues in developing human capital for the workplace. There is thus a need for some social transformation of language in the education system, for as long as African languages are not used in formal circles, corresponding economic empowerment cannot be realised.

Recognising, promoting and developing a language enhance the achievement of equality which ensures social, economic, governmental and educational objectives. Mutasa (2003: 38) admits that this strategy is very appropriate in solving language problems in a multilingual society. That way all languages would contribute substantially to the development of a country. If African languages and literatures were to be studied through formal education, the indigenous people could be empowered socially, culturally and economically (Mavesera, 2009: 20). Languages that people are able to communicate in are critical for personal as well as national development. Formal education then provides the necessary skills that help polish communication skills. The school is the most appropriate forum for preparing young people for effective participation in nation building, both social and economic.

Although Bamgbose (1991) refers to mother-tongue education as being essential in adult literacy programmes, this article adopts and adapts this line of thinking in terms of work life, basing on a new concept of literacy evolved by UNESCO in 1960. UNESCO links literacy learning (read, write and count) to a learner's work situation and his/her environment. 'The assumption is that if a person sees the prospect of his economic interests being enhanced by literacy, he will be more inclined to pay serious attention to it', as Bamgbose (1991: 95) notes. In the same way a housewife is enabled to learn about childcare, environmental sanitation and nutrition through mother-tongue education in adult literacy, a broadcaster, for example, should also be made effective and competent in language through mother-tongue education.

\section{LANGUAGE POLICY IN ZIMBABWEAN EDUCATION}

The Education Act (1987) has been the basis for language issues in Zimbabwe. English is the language of business, administration and international relations. It is a compulsory subject 
throughout the whole education ladder up to employment levels. English has been a language of instruction from Grade 4 upwards, and unofficially even at lower levels. Shona and Ndebele are also taught up to university, but not on compulsory terms. The other indigenous languages are now being introduced after the amendment of the Education Act. However, having a pass in English is still valued by individuals for further education and in industry and commerce. Schools are therefore motivated to teach those subjects that give them and the school-leaver a good positioning nationally and an opportunity to be absorbed into industry respectively.

Colonial language policies continue to influence and be reflected in the current language policy in education. The situation is no different from what used to obtain during the British South Africa Company's regime when bilingualism did not benefit the black African (Mavesera, 2009). As if that was not enough, missionary influence on language in and of education fuelled the situation. Some 34 years into independence, things have not changed much. English is still the language of legislation, courts, education and commerce. English is still more developed than the African languages and continues to be a global language, a language of wider communication, of documents and technology. To compound all that, there still is not much being done to come up with a tangible language policy, save for a set of constitutional clauses which are amended from time to time.

The education ministry, through the Secretary's Circular Number 1 of 2002, directed that: local languages be taught up to Grade 7 by the year 2005; Ndebele and Shona be given equal status to English concerning teaching hours, materials provision and research; and Shona and Ndebele languages be made compulsory subjects up to Form 2 level. Despite such sound and promising declarations, very little has happened even up to this day. Attempts to redress language in education made through the Education Act have not been that effective (Mutomba, 2007). This article considers such realities in arguing for redefining the language curriculum in Zimbabwean high schools.

\section{LINGUISTIC ATTITUDE AND PERCEPTION}

Madadzhe and Sepota (in Mutasa, 2006) reckon that negative attitudes towards African languages play a major role in their unpopularity. Alenezi (2010) also contends that, although language educational policies are often imposed by governing bodies such as the education ministry, it is the teachers and learners who are affected by the language selection. Because the people on the educational ground are excluded from language planning, wrong attitudes and perceptions towards African languages are bound to develop.

Derhemi (2002) maintains that linguistic attitudes are historical and cultural constructs, and relate directly to the prestige of a language. Skutnabb-Kangas (in Ouane, 2003) also accuses politicians and some researchers who argue against maintenance of endangered languages while indirectly promoting the English language. Such scholars argue that including African languages in the curriculum is very costly. This article argues that there is no educational programme that does not consume money. Therefore, governments should not treat African language education as an unmanageable cost. Thus, the article maintains that curriculum should change to accommodate the interests and needs of studying African languages for the work environment.

Per Linguam 2015 31(1):74-88

http://dx.doi.org/10.5785/31-1-634 


\section{LANGUAGE AND HUMAN RESOURCES}

Human resources are the most important assets in any society or field. Improving preparation of human resources should be the core of any sustainable solution to any profession. Adjibolosso (1995: ix) contends that ' $\ldots$ it is the people who make things either happen or fail to happen'. Performance depends on knowledge, skills and motivation. No human activity or business can be pursued successfully without people who are readily equipped, responsible and accountable, and willing to participate in progress aimed at development. Future staff needs ensure that a sufficient pool of skilled and motivated people with the right skills mix and experience will be available to meet the organisational needs in the long term. It is important to place people in the right jobs and retain them where they are most needed.

The general tendency is to think that training and development are not essential in African languages areas. There is little discussion with regard to the training and development requirements of particular professions involving African languages. However, there is a need to emphasise that more structured and specific forms of training and development are required due to the unique nature of African languages. Failure to prioritise the attraction of young talent to develop the use and status of indigenous languages ends up causing a steady attrition in talent. This is a major concern in this article, as the training and development of a labour force in local languages has suffered as a result of biased language policies over years.

\section{EVALUATION OF COLONIAL EDUCATION AND POST-INDEPENDENCE EDUCATION IN ZIMBABWE}

Policies under the British South African Company rule set apart English as the official language, and the tendency was to regard African languages as crude and uncivilized (Ngara, 1982). English held a central position in the curriculum, whereas Shona and Ndebele received minimal space in black schools and none in white schools. The thinking that guided the provision of education to the indigenous people and language policies was determined by how the culture, aspirations and potentials of the indigenous population were perceived during that time (Magwa, 2008). This on its own shows that Zimbabwe's linguistic status is no different from that of many former colonial states in Africa. The education systems in colonial Africa were characterised by problems. Having identified the root causes of the problem, the next section of this article explores how far post-independence education has gone in addressing these ills.

It is a fact that, on attainment of independence, African governments invested heavily in educational expansion and diversification (Mavhunga, 2006; Woolman, 2001). The investments have resulted in rises in terms of enrolment, literacy, skilled human resources and educational facilities, despite the limited resources with which the governments operated. However, gains along those terms seem to have failed to improve the lives of most Africans, perhaps because no attention has been given to languages issues. Language, particularly mother tongue, is critical in education, yet the education system continues to ignore that.

Magwa (2008: 16) decries that in post-independence Zimbabwe there is ' $\ldots$ perpetual denial of indigenous languages to be given a chance to flourish and help promote African culture and identity', hence the need for an urgent redress of such an imbalance. To that effect, Magwa (ibid.) suggests that Zimbabwe needs a 'final push' towards the total emancipation of indigenous people by the intensive and extensive use of indigenous languages. The zeal which Zimbabwe is Per Linguam 2015 31(1):74-88 http://dx.doi.org/10.5785/31-1-634 
showing in the fight for land redistribution is the kind that is also expected in defending indigenous languages in schools. This can only be realised if African languages are afforded better currency in the school system and economic sphere. Unless African languages are viewed with pride by the school curriculum, there arises a situation where human resource management and development in related areas suffer.

The evaluation of colonial and post-independence education has persuaded some African scholars to re-examine the objectives, methods and outcomes of pre-colonial forms of traditional education (Mavhunga, 2006; Woolman, 2001) and consequently guide the route for post-colonial social reconstruction through education. Some critical reviews of educational reforms in Africa have recommended strategies like reorganisation of content, reduction of subjects due to student overload, building national unity, education for all, and knowledge based on science and technology for rapid industrialisation, without paying attention to language-in-education policies and curriculum revision (Rwantabangu, 2011). In light of that shortcoming, Woolman (2001) emphasises that curriculum revision provides another measure of post-independence educational reconstruction in Africa.

What does all this mean to the education policymaker in Zimbabwe? This article proposes that the current Zimbabwean curriculum be restructured to create products fit for African languages' expertise. Curriculum development that is guided by educational reconstruction considers current and future needs of a society as the way forward.

\section{THE WAY FORWARD FOR ZIMBABWE}

The discussion above has presented challenges relating to the relevance and worthwhileness of the study of African languages in Zimbabwean high schools. The question that needs to be addressed is: How can perceptions and attitudes towards African languages be improved in order to impact positively on human resource potential in related areas? This article suggests reconstruction of the core curriculum. Adesoji (2003) calls this strategy Africanising the curriculum. Africanising the curriculum, according to Adesoji (2003) and Mavhunga (2006), simply means making the curriculum meet the needs, interests and aspirations of the African people as determined by the Africans themselves.

This article suggests some critical areas that need to be attended to in a bid to Africanise the study of languages in Zimbabwean high schools. The most important one is the crafting of an educational philosophy that encapsulates the value and importance of the study of African languages in high school. Beginning 2013, the ministry responsible for primary and secondary education is busy reviewing the school curriculum, and this is an opportune time for curriculum planners to also bring the issue of language in education under review. Besides making African languages, languages of instruction in schools, the curriculum planners and developers should make it policy that the languages become part of the core curriculum in practice. This would place African languages on track for a better status.

Similarly, African languages should be a made prerequisite for entry into universities and other tertiary institutions, just as is happening with the English language. This would reduce the loss of talent in African languages which culminates in an equally huge loss of potential human resources, especially in related fields. One school product might be gifted in African languages 
but derailed and misplaced only because of the non-inclusive requisite guidelines currently in operation.

The government should also find means and ways of promoting and empowering the study of African languages in high schools such that those with potential in the area are attracted into the discipline. This could be in the form of financial injections, like bursaries and scholarships, targeted at the teaching and learning of African languages. Such strategies have been employed where science and practical subjects are concerned, and the same could be done with African languages. Further, incentives for those teaching African languages, in the form of perks and scholarships for further studies, should be introduced. The government and other stakeholders should establish scholarships for those studying African languages. This would draw muchneeded talent in disciplines that draw from African languages specialisation. This would facilitate in making African languages compulsory subjects of the school curriculum, which would also promote additive bilingualism.

Research is one of the mandates of institutions of higher learning. Universities should, therefore, be encouraged to carry out more intensive and extensive research into African languages, especially in terms of authorship, lexicography and translation. That research culture would naturally cascade into colleges and schools. This is the only way to build on the existent literary corpus on African languages. It also indirectly boosts human potential in the areas. In addition, tertiary institutions should focus on development of human resources for African languagesrelated fields so as to address the multilingual context of the country. More should be done in terms of training in teacher education, editing, translation, writing, interpretation, news reading and news reporting with an African languages bias.

The same can be done in specialised research whereby institutes for African languages, such as the African Languages Research Institute at the University of Zimbabwe, should be increased in the same manner as there are numerous institutes for technical apprenticeship. This would create lucrative jobs in the area, meaning that such institutes should be well-resourced in terms of human and financial capital. This would promote the development of African languages, which directly affects study of the languages. In the same vein, speakers of African languages should promote their languages by using them in all domains whenever it is feasible. Languages develop through use.

Only those people with sound educational background and proficiency in African languages should be allowed to write for, edit and present on television and radio and in newspapers. Teaching of African languages should be done by trained teachers only, who should have specialised in the respective language. The bottom line is, African languages-related jobs should be taken up by more relevant personnel; those that have specialised in African languages and the skill that should be employed in the specific post. This would erase distortions in casts like news editing, reading and reporting on television and radio. The right perceptions and attitudes towards the languages would be inculcated that way.

There should be some awareness-raising campaigns to conscientise students, parents, the general populace and policymakers on the importance of studying African languages. Similarly, vigorous career guidance in high schools with a bias towards African languages should be instituted. This would help many students in plotting or mapping out their career path more informatively. 
The ministry responsible for education should think of using English alongside African languages as media of instruction in some subjects, like humanities, for a start until such a time when appropriate technical jargon has been developed for respective school subjects. Bilingual education places school products at an advantage nationally, regionally and internationally. Mother-tongue education could then be treated as an asset rather than a liability as is the case at the moment.

African languages could be officially declared languages of the work place since in practice they are already languages of the work place. This raises their status in terms of usefulness and prestige.

The suggestions given above, for more serious refocusing of language in education in Zimbabwean high schools, do not advocate for a situation which renders products of the system non-functional in the world beyond the borders. Rather, the thrust is that, while taking into account concepts of globalisation and modernisation, the Zimbabwean education system should realise that it is in a multilingual context which is dominated by speakers of African languages. Human resource management and development should recognise and take into account the importance of local languages, which should be preserved and promoted.

\section{CONCLUSION}

The language issue in African education is contentious. From the picture portrayed in this article, it has been argued that colonial language education policy has remained largely intact despite some tinkering with it in post-independence educational reforms, which continue to promote and perpetuate the English language at the expense of African languages. Negative perceptions and attitudes towards African languages have continued unabated, leading to unprecedented discord in human resource issues in areas affected. This, therefore, calls for a re-look at language education policy with the view to Africanising as an attempt to redress the situation.

Human resource potential in African languages might not be realised without serious consideration of the significance of studying African languages in high schools. The education system should view African languages as the local people's greatest economic, cultural, moral and social inheritance, which should be learned by individuals through formal education. National economic, cultural, moral and social gains can only be realised when the study of African languages in high schools is taken as part of the core curriculum.

\section{REFERENCES}

ADESOJI, OA. 2003. Globalisation: a menace to African values and education. Zimbabwe Journal of Educational Research, 15(1):51-61.

ADJIBOLOSSO, SB-SK. (Ed). 1995. The significance of the human factor in African economic development. London: Praeger Publishers.

ADJIBOLOSSO, SB-SK. 1996. The human factor in developing Africa. Westport: Praeger Publishers.

AKINPELU, JA. 1985. An introduction to philosophy of education. Princeton: Merrill Publishing Company.

ALENEZI, AA. 2010. Students' language attitude towards using code-switching as a medium of instruction in the College of Health Sciences: an exploratory study. ARECLS, 1:1-22.

Per Linguam 2015 31(1):74-88

http://dx.doi.org/10.5785/31-1-634 
BAMGBOSE, A. 1991. Language and the nation: the language question in Sub-Saharan Africa. Edinburg: Edinburg University Press.

BENSON, C. 2004. The importance of mother tongue-based schools for educational quality. UNESCO: Education for All Global Monitoring Report 2005.

BRAMELD, T. 1971. Reconstructionism. The encyclopedia of education, 7:425-428. New York: MacMillan.

CHAPANGA, E \& R MAKAMANI. 2006. Teaching Shona in English/Shona: ideological challenges and implications - Whither UZ and MASU? Zimbabwe Journal of Educational Research, 18(3):383397.

DERHEMI, E. 2002. Thematic introduction: protecting endangered minority languages: sociolinguistic perspectives. International Journal on Multicultural Societies, 4(2):150-161.

DUBE, M. 2012. The Zimbabwe Indigenous Languages Promotion Association (ZILPA) position paper, presented in the Faculty of Education, University of Zimbabwe, 12 September 2012.

FERGUSON, CA. 1959. Diglossia. Word, 15:324-40.

FISHMAN, J. 2002. Endangered minority languages: prospects for sociolinguistic research. International Journal on Multilingual Societies, 4(2):270-275.

GORA, R, G MAVUNGA, B MURINGANI \& F WANIWA. 2010. The use of Shona as a medium of instruction in the first three grades of primary school in Tonga speaking community: parents' and teachers' perceptions. Zimbabwe Journal Educational Research, 22 (1):87-102.

GORA, RB. 2014. Perception and attitude towards the study of African languages in Zimbabwean high schools: implications for human resources development and management. Unpublished DPhil thesis. Pretoria: University of South Africa.

GOVERNMENT OF ZIMBABWE. 1987. Education Act. Harare: Government Printers.

GOVERNMENT OF ZIMBABWE. 2002. Ministry of Education Secretary's Circular No. 1. Harare: Government Printers.

GOVERNMENT OF ZIMBABWE. 2006. Amended Education Act. Harare: Government Printers.

GUDHLANGA, ES \& G MAKAUDZE. 2005. Promoting the use of African languages as a medium of instruction of higher learning in Zimbabwe: the case of MASU's Department of Languages, Literature and Music. Unpublished paper presented at a conference, Durban, University of KwaZulu-Natal.

HACHIPOLA, JS. 1998. A survey of the minority languages of Zimbabwe. Harare: University of Zimbabwe Publications.

KNELLER, GF. 1971. Introduction to the philosophy of education, $2^{\text {nd }}$ Edition. USA: John Wiley and Sons, Inc.

MAGWA, W. 2008. Planning for the future: exploring possibilities of using indigenous African languages as languages of instruction in education - the Zimbabwean experience. Unpublished DPhil thesis. Pretoria: University of South Africa.

MAVESERA, M. 2009. Empowerment through language: exploring possibilities of using African languages and literature to promote socio-cultural and economic development in Zimbabwe. Unpublished DPhil Thesis. Pretoria: University of South Africa.

MAVHUNGA, PJ. 2006. Africanising the school curriculum: a case for Zimbabwe. Zimbabwe Journal of Education Research, 18(3):440-456.

MAZRUI, AA. 1978. Political values and the educated class in Africa. Berkeley: University of California Press.

MNKANDLA, M. 2000. An investigation of the implementation of Zimbabwe's language policy in primary education. Zimbabwe Journal of Educational Research, 12(1):75-99.

MUTASA, DE. 2003. The language policy of South Africa: what do people say? Unpublished DPhil Thesis. Pretoria: University of South Africa.

MUTASA, DE. 2006. African languages in the $21^{\text {st }}$ century: the main challenges. In Mutasa, DE (Ed), African languages in the $21^{s t}$ century: the main challenges. Pretoria: Simba Guru Publishers.

Per Linguam 2015 31(1):74-88

http://dx.doi.org/10.5785/31-1-634 
MUTOMBA, V. 2007. An investigation into the effectiveness of the Education Act in selected Zimbabwean primary schools in Harare. Unpublished MEd dissertation. Harare: University of Zimbabwe.

NGARA, EA. 1982. Bilingualism, language contact and language planning: proposal for language use and language teaching in Zimbabwe. Gweru: Mambo Press.

NZIRAMASANGA COMMISSION. 1999. Report on the presidential commission of enquiry into education and training. Harare: Government Printers.

OFORI-AMOAH, B. 1995. The saturation hypothesis and Africa's development theory and its implications for the human factor in Africa's development. In Adjibolosso, SB-SK (Ed), The significance of the human factor in African economic development. London: Praeger Publishers.

OUANE, A. (Ed). 2003. Towards a multilingual culture of education. Hamburg: UNESCO Institute for Education.

OZMON, HA \& SM CRAVER. 1986. Philosophical foundations of education. Columbus: Merrill Publishing Company.

PRAH, KK. 2005. Language of instruction for education development and African emancipation. In Brock-Utne, B \& RK Hopson (Eds), Languages of instruction for African emancipation: focus on post-colonial contexts and considerations. Cape Town: The Centre for Advanced Studies of African Society. 23 - 50.

RWANTABANGU, H. 2011. Tradition, globalisation and language dilemma in education: African options for the $21^{\text {st }}$ century. International Review of Education, 1(22): 1-15.

UJU, CC. 2008. Language science, technology and mathematics and poverty alleviation in Africa: a case of Nigeria. Zimbabwe Journal of Educational Research, 20(1):22-29.

WARDHAUGH, P. 1998. An introduction to sociolinguistics. Massachusetts: Blackwell Publishers.

waTHIONG'O, N. 1996. Decolonising the mind: the politics of language in African literature. London: James Currey.

WEBB, V. 2002. Language in South Africa: the role of language in national transformation, reconstruction and development. Amsterdam: John Benjamins Publishing Company.

WOOLMAN, DC. 2001. Educational reconstruction and post-colonial curriculum development: a comparative study of four African countries. International Education Journal, 2(5): 27-46.

\section{BIOGRAPHICAL NOTE}

Davie Mutasa is a professor in the department of African Languages at the University of South Africa. He has published on the Shona language and language planning. He has presented papers in Lesotho, Zimbabwe, The Netherlands, Jamaica, Australia, Malaysia, the USA, Hawaii, China and Norway. He has supervised more than 30 postgraduate students. He was invited by the former Minister of Education, Naledi Pandor, to address the department and serve as one of the advisors on language policy. He featured on radio discussing language matters and has creative works in the form of three Shona novels. Email: mutasde@unisa.ac.za

Ruth Babra Gora is a senior lecturer at the University of Zimbabwe in the Department of Curriculum and Arts Education. She has published in a number of academic journals and has also contributed some book chapters. Her research interests are in language policy and planning, language and gender, and language and teacher education. Email: goraruth@yahoo.com

Per Linguam 2015 31(1):74-88

http://dx.doi.org/10.5785/31-1-634 